\title{
Penggunaan Asas Beban Pembuktian Terbalik sebagai Penyelesaian Perkara Kesalahan yang Dilakukan Oleh Dokter
}

\author{
Randika Fitrah Darmawan ${ }^{1 *}$, Slamet Sampurno Soewondo ${ }^{2}$, Sabir Alwi ${ }^{3}$ \\ 1, 2, 3 Pascasarjana Ilmu Hukum Universitas Hasanuddin, Makassar, Indonesia \\ *E-mail: randika.darmawan125@gmail.com
}

\begin{tabular}{l}
\multicolumn{1}{c}{ Dikirim: $11 / 11 / 2020$} \\
\hline Info Artikel \\
\hline Keywords: \\
Error; Reversed \\
Evidence; Legal \\
Protection. \\
\\
\\
Kesalahan; \\
Pembuktian Terbalik; \\
Perlindungan Hukum. \\
Kata Kunci
\end{tabular}

\begin{tabular}{l} 
Direvisi: 22/05/2021 \\
\hline Abstract \\
\hline This study aims to identify and analyze criminal procedural law
\end{tabular}
arrangements in resolving cases of wrongdoing committed by doctors; and legal protection for patients in reverse proof of the settlement of wrongdoing by doctors. The research method used is normative juridical research, the type of research is descriptive analytical. The source of legal materials is primary and secondary legal materials. The technique of collecting legal materials is carried out by library research on legal materials, both primary legal materials, secondary legal materials, to complement the legal materials collected, interviews are conducted with experts or resource persons selected based on the authority exercised by the relevant In this paper, analysis of legal materials is descriptive qualitative, namely identifying primary and secondary legal materials that will be carried out in analyzing problems in a series of processing stages by carrying out an inventory, systematizing, to make it easier to analyze these problems. Based on the analysis, the authors conclude several things, including: (1) the system of proof of criminal procedural law in the process of resolving a case of wrongdoing committed by a doctor still uses the usual burden of proof as stated in article 66 of the criminal procedural code (KUHAP); (2) providing legal protection to patients under the burden of proof reversed on the settlement of wrongdoing committed by doctors can be seen using: 1. Philosophical Approach, 2. Juridical Approach, 3. Theoretical Approach, and 4. Social Approach.

Abstrak
Penelitian ini bertujuan untuk mengetahui dan menganalisis pengaturan
hukum acara pidana dalam penyelesaian perkara kesalahan yang dilakukan
oleh dokter; dan perlindungan hukum terhadap pasien dalam pembuktian
terbalik pada penyelesaian perkara kesalahan yang dilakukan oleh dokter.
Metode penelitian yang digunakan adalah penelitian yuridis normatif, tipe
penelitian bersifat deskriptif analitis. Sumber bahan hukum yang
digunakan bahan hukum primer dan bahan hukum sekunder. Teknik
pengumpulan bahan hukum dilakukan dengan studi pustaka (library
research) terhadap bahan-bahan hukum baik bahan hukum primer, bahan
hukum sekunder, untuk melengkapi bahan-bahan hukum yang
dikumpulkan maka dilakukan wawancara dengan para pakar atau
narasumber yang dipilih berdasarkan otoritas yang dijalankan oleh terkait
pada penulisan ini, Analisis bahan hukum adalah deskriptif kualitatif yaitu


DOI:

10.47268/sasi.v27i2.426

mengidentifikasikan bahan hukum primer dan sekunder yang akan dilakukan dalam menganalisis permasalahan dalam rangkaian tahapan pengolahan dengan melakukan inventarisasi, sistematisasi, untuk mempermudah menganalisis permasalahan ini. Berdasarkan analisis, penulis menyimpulkan beberapa hal, antara lain: (1) sistem pembuktian hukum acara pidana dalam proses penyelesaian perkara kesalahan yang dilakukan oleh seorang dokter masih menggunakan beban pembuktian secara biasa hal ini sebagaimana tertuang dalam Pasal 66 kitab undangundang hukum acara pidana (KUHAP); (2) pemberian perlindungan hukum terhadap pasien dalam beban pembuktian terbalik pada penyelesaian perkara kesalahan yang dilakukan oleh dokter dapat dilihat dengan menggunakan: 1. Pendekatan Filosofi, 2. Pendekatan Yuridis, 3. Pendekatan Teoritis, dan 4. Pendekatan sosial.

\section{A. PENDAHULUAN}

Hukum merupakan suatu hal yang cukup penting dalam kehidupan berbangsa dan bernegara. Cita hukum bangsa dan negara Indonesia adalah pokok-pokok pikiran yang terkandung dalam pembukaan Undang- Undang Dasar 1945, untuk membangun negara yang merdeka, bersatu, adil, dan makmur. Cita hukum itulah Pancasila ${ }^{1}$. Sebagai Negara yang berlandaskan hukum sudah seharusnya segala aspek yang hadir didalam Negara haruslah diatur sehingga akan tercapainya konsep penegakan hukum yang adil, bermanfaat dan berkepastian hukum, tak luput pula dari segi kesehatan.

Pelayanan kesehatan pada dasarnya bertujuan untuk melaksanakan upaya pencegahan dan pengobatan suatu penyakit, termasuk di dalamya pelayanan medis yang didasarkan atas dasar hubungan individual antara dokter dengan pasien yang membutuhkan kesembuhan atas penyakit yang dideritanya. Dokter merupakan pihak yang mempunyai keahlian di bidang medis atau kedokteran yang dianggap memiliki kemampuan dan keahlian untuk melakukan tindakan medis. Sedangkan pasien merupakan orang sakit yang awam akan pengetahuan penyakit yang dideritanya dan mempercayakan dirinya untuk diobati dan disembuhkan oleh dokter. Oleh karena itu dokter berkewajiban memberikan pelayanan medis yang sebaik-baiknya bagi pasien.

Sering terjadinya kealpaan atau kelalaian yang merupakan bentuk kesalahan yang tidak berupa kesengajaan, akan tetapi juga bukan merupakan sesuatu yang terjadi karena kebetulan. Jadi dalam kealpaan ini tidak ada niat jahat dari pelaku. Kealpaan atau kelalaian dan kesalahan dalam melaksanakan tindakan medis menyebabkan terjadinya ketidakpuasan pasien terhadap dokter dalam melaksanakan upaya pengobatan sesuai profesi kedokteran. Kealpaan dan kesalahan tersebut menyebabkan kerugian berada pada pihak pasien. ${ }^{2}$ Adapun mengenai persoalan sebuah indikasi kesalahan maupun kelalaian yang dilakukan oleh seorang dokter merupakan suatu indikasi kesalahan yang dilakukan dalam keadaan menjalankan profesinya. adapun beberapa undang undang yang mengatur tentang proses penyelesaian indikasi Kesalahanyang dilakukan oleh seorang dokter diatur dalam beberapa undang-undang khusus diantaranya : 1. Undang-Undang Nomor 29 Tahun 2004 Tentang Praktik Kedokteran; 2. Undang-Undang Nomor 36 Tahun 2009 Tentang Kesehatan; 3. Undang-Undang Nomor 44 Tahun 2009 Tentang Rumah Sakit.

Dalam Pasal 5 ayat(2) Undang-Undang Nomor 36 Tahun 2009 tentang kesehatan yang selanjutnya akan disebut UU Kesehatan menyebutkan bahwa Setiap orang mempunyai hak dalam memperoleh pelayanan kesehatan yang aman, bermutu, dan terjangkau. Selanjutnya

1 Tambunan, L. (2014), Implementasi Perlindungan Hukum Terhadap Anak Sebagai Korban Kekerasan Psikis Dalam Rumah Tangga, Jurnal Hukum, 1-24, http://e-journal.uajy.ac.id/7172/, h. 11.

2 Erdiansyah. (2016), Pertanggungjawaban Pidana Terhadap Dokter Atas Kesalahan Dan Kelalaian Dalam Memberikan Pelayanan Medis Di Rumah Sakit, Jurnal Ilmu Hukum, 3(2).

$$
\text { 137|SASI Vo1.2 } 7 \text { No.2, April - Juni } 2021
$$


Pasal 58 ayat(1) UU Kesehatan menyebutkan bahwa : Setiap orang berhak menuntut ganti rugi terhadap seseorang, tenaga kesehatan, dan/atau penyelenggara kesehatan yang menimbulkan kerugian akibat kesalahan atau kelalaian dalam pelayanan kesehatan yang diterimanya.

Namun Dalam kenyataannya, kasus yang terjadi di Rumah Sakit Haulussy Ambon pada tanggal 4 mei 2016 yang diduga salah penanganan terhadap bayi berusia 3 hari dan akhirnya meninggal dikarenakan kekurangan bukti yang didapatkan sehingga kasus tersebut tak dapat dilanjutkan. Selain itu berdasarkan data yang diterima oleh Lembaga Bantuan Hukum (LBH) Jakarta laporan masyarakat di kepolisian terkait dugaan malpraktik (Kesalahanyang dilakukan oleh dokter), bahkan banyak yang dihentikan. hal ini dikarenakan polisi selalu mendasarkan penyelidikannya pada pernyataan ahli, disisi lain korban (Pasein) yang meminta seorang dokter untuk memberikan keterangan akan tetapi kebanyakan dokter enggan memberikan kesaksian.

\section{B. METODE PENELITIAN}

Tipe penelitian yang digunakan adalah yuridis normatif. Metode pendekatan dalam penelitian ini adalah: 1. Pendekatan peraturan perundang-undangan (statue aproach) untuk menganalisis permasalahan yang ada agar dapat menjawab permasalahan secara komprehensif. ${ }^{3}$ dan 2. Pendekatan Konseptual (Conceptual Approach) Yaitu penelitian yang beranjak dari pandangan-pandangan dan doktrin-doktrin di dalam ilmu hukum, peneliti akan menemukan ide-ide yang melahirkan pengertian-pengertian hukum, konsep konsep hukum dan asas-asas hukum yang relevan dengan isu yang dihadapi, Sumber Bahan Hukum yang digunakan dalam penelitian ini adalah : a. Bahan Hukum Primer yang terdiri dari perundangundangan; dan b. Bahan Hukum Sekunder adalah memberikan penjelasan mengenai bahan hukum primer yang terdiri dari pendapat ilmiah para sarjana dan buku-buku literatur, kamus hukum, ensiklopedia dan sebagainya, Teknik pengumpulan bahan hukum yang digunakan pada penulisan ini dilakukan dengan studi pustaka (Library Research) terhadap bahan-bahan hukum baik bahan hukum primer, bahan hukum sekunder, serta Analisis bahan hukum yang digunakan oleh penulis adalah deskriptif kualitatif.

\section{PEMBAHASAN}

\section{Pengaturan Hukum Acara Pidana dalam penyelesaian perkara Kesalahanyang dilakukan oleh Dokter}

Kesalahan dalam Bahasa belanda disebut "schuld" adalah salah satu unsur utama, dengan pertanggungjawaban pelaku terhadap perbuatannya, termasuk perbuatan pidana atau tindak pidana/delik. Unsur-unsur tersebut demikian pentingnya, sehingga ada adagium yang terkenal yaitu "tiada pidana tanpa kesalahan" yang didalam Bahasa belanda adalah "geen straf zonder schuld" dan dalam Bahasa jerman, "keine strafe ohne schuld".

Suatu adagium menyebutkan bahwa "Actus non facit reum, nisi mens sit rea" yang artinya perbuatan tidak membuat orang bersalah, kecuali jika terdapat sikap batin yang salah, jadi batin yang salah atau guilty mind atau (mens rea) inilah kesalahan yang merupakan sifat subjektif dari tindak pidana, karena berada didalam diri pelaku. Oleh karena itu kesalahan merupakan unsur yang bersifat subjektif dari tindak pidana, maka kesalahan juga memiliki dua segi, yaitu segi psikologis dan segi yuridis. Ditinjau dari segi psikologis kesalahan itu harus dicari di dalam batin pelaku, yaitu adanya hubungan batin dengan perbuatan yang dilakukan ${ }^{4}$.

Adapun unsur unsur kesalahan adalah: ${ }^{5}$

3 Marzuki, P. M. (2017). Penelitian Hukum. Edisi Revisi, Jakarta: Kencana, h. 29

4 Ratnasari, D., Lasmadi, S., \& Sudarti, E. (2021). Kedudukan Hukum Deponeering dalam Sistem Peradilan Pidana. PAMPAS: Journal of Criminal Law, 2(1), 17-29. h. 8.

5 Maggalatung, A. S. (2014). Hubungan Antara Fakta Norma, Moral, Dan Doktrin Hukum Dalam Pertimbangan Putusan Hakim. Jurnal Cita Hukum, 2(2). h 4.

$$
\text { 138|S A S I Vol. } 27 \text { No.2, April - Juni } 2021
$$


1) Adanya kemampuan bertanggung jawab pada si pelaku, dalam arti jiwa si pelaku dalam keadaan sehat dan normal.

2) Adanya hubungan batin antara si pelaku dengan perbuatannya, baik yang disengaja (dolus) maupun karena kealpaan (culpa).

3) Tidak adanya alasan pemaaf yang dapat menghapus kesalahan.

Selanjutnya kelalaian merupakan salah satu bentuk kesalahan yang timbul karena pelakunya tidak memenuhi standar perilaku yang telah ditentukan menurut undang-undang, kelalaian itu terjadi dikarenakan perilaku orang itu sendiri, dalam hal kejahatan yang dilakukan dengan kesengajaan misalnya sengaja membunuh, sengaja mencuri, dan lain sebagainya, telah terlihat bahwa kehendak untuk melakukan suatu tindak pidana dalam arti sikap batin seseorang jelas jelas menentang suatu larangan dalam undang-undang dan dia mengetahui akibatnya yang akan timbul dari tindakan tersebut (weents en willens) ${ }^{6}$. Sementara dalam hal kejahatan kealpaan, sikap batin orang yang menimbulkan keadaan yang dilarang itu bukanlah menentang larangan-larangan tersebut, dia tidak menghendaki atau menyetujui timbulnya hal terlarang, tetapi kesalahannya, kekeliruannya dalam batin sewaktu dia berbuat sehingga menimbulkan hal yang dilarang ialah bahwa dia kurang mengindahkan larangan itu. ${ }^{7}$

Pembuktian dalam perkara Pidana merupakan inti persidangan pidana dalam sistem peradilan umum di Indonesia untuk mencari kebenaran materiil. ${ }^{8}$ Pembuktian Pidana tersebut telah dimulai sejak tahap penyelidikan guna menemukan dapat tidaknya dilakukan penyidikan dalam rangka membuat terang suatu tindak pidana dan menemukan tersangka dari tindak pidana tersebut.

Menurut Martiman Prodjohamidjojo, bahwa pembuktian adalah mengandung maksud dan usaha untuk menyatakan kebenaran adalah suatu peristiwa, sehingga dapat diterima oleh akal terhadap kebenaran peristiwa tersebut. Dalam hukum acara pidana, acara pembuktian adalah dalam rangka mencari kebenaran materiil dan KUHAP yang menetapkan tahapan dalam mencari kebenaran sejati yaitu melalui: a. Penyidikan; b. Penuntutan; c. Pemeriksaan di persidangan; d. Pelaksanaan, pengamatan, dan pengawasan.Sehingga acara pembuktian hanyalah merupakan salah satu fase atau prosedur dalam pelaksanaan hukum acara pidana secara keseluruhan sebagaimana diatur didalam KUHAP. ${ }^{9}$ Berdasarkan penjelasan diatas diketahui bahwa pembuktian merupakan suatu unsur yang cukup penting dalam menerangkan suatu perkara sehingga menciptakan suatu proses peradilan yang mencerminkan nilai keadilan.

Hukum pembuktian merupakan sebagian dari hukum acara pidana yang mengatur macam-macam alat bukti yang sah menurut hukum, sistem yang dianut dalam pembuktian, syarat-syarat dan tata cara yang mengajukan bukti tersebut serta kewenangan hakim untuk menerima, menolak dan menilai suatu pembuktian. Adapun sumber-sumber hukum pembuktian adalah, sebagai berikut: a). Undang-undang; b). Doktrin atau ajaran; c). Yurisprudensi.

Kekuatan pembuktian dalam hukum acara pidana terletak didalam Pasal 183 Undangundang Nomor 8 Tahun 1981 tentang Hukum Acara Pidana, yang berbunyi ,hakim tidak boleh menjatuhkan pidana kepada sesorang kecuali apabila dengan sekurang-kurangnya dua alat bukti yang sah ia memperoleh keyakinan bahwa suatu tindak pidana benar-benar terjadi dan bahwa terdakwalah yang bersalah melakukannya. Berdasarkan ketentuan tersebut bahwa seorang hakim dalam memutuskan suatu perkara pidana harus berdasarkan minimal dua alat

${ }^{6}$ Darmadi, A. S. M. Y. (2018). Pertimbangan Hakim Dalam Menjatuhkan Putusan Pidana Bersyarat. Jurnal Advokasi, 8(2), 179-191. h, 3.

7 Sengi, E. (2019). Konsep Culpa Dalam Perkara Pidana Suatu Analisis Perbandingan Putusan Nomor 18/Pid. B/2017/PN. Tobelo. Era Hukum-Jurnal Ilmiah Ilmu Hukum, 17(2). h. 2.

8 Ali, A. (2017). Menguak Tabir Hukum: Ed. 2, Jakarta: Kencana. 2017. h. 97

9 Nakamnanu, M. J. (2016), Kekuatan Pembuktian Alat Bukti Informasi Atau Dokumen Elektronik Dalam Peradilan Perkara Pidana Korupsi, Jurnal Hukum. h. 2.

$$
\text { 139|SASI Vol. } 27 \text { No.2, April - Juni } 2021
$$


bukti yang sah. Apabila sebaliknya maka terdakwa tidak dapat diajutuhi hukuman atas tindakannya. ${ }^{10}$

Dalam hal proses penyelesaian kasus dugaan indikasi Kesalahanyang dilakukan oleh seorang dokter, alat bukti yang sering digunakan adalah :

1) Informed Consent

Informed Consent teridiri dari dua kata yaitu "informed" yang berarti informasi atau keterangan dan "consent" yang berarti persetujuan atau memberi izin. jadi pengertian Informed Consent adalah suatu persetujuan yang diberikan setelah mendapat informasi. Dengan demikian Informed Consent dapat di definisikan sebagai pernyataan pasien atau yang sah mewakilinya yang isinya berupa persetujuan atas rencana tindakan kedokteran yang diajukan oleh dokter setelah menerima informasi yang cukup untuk dapat membuat persetujuan atau penolakan. Persetujuan tindakan yang akan dilakukan oleh Dokter harus dilakukan tanpa adanya unsur pemaksaan. ${ }^{11}$ Dasar Hukum mengenai Informed Consent dapat diatur dalam Pasal 45 Undang Undang No. 29 tahun 2004 tentang Praktik Kedokteran.

2) Rekam Medis

Pengertian Rekam Medis menurut Permenkes Nomor 269/Menkes/Per/III/2008 tentang Rekam Medis adalah berkas yang berisikan catatan dan dokumen tentang identitas pasien, pemeriksaan, pengobatan, tindakan dan pelayanan lain yang telah diberikan kepada pasien. Rekam medis merupakan milik rumah sakit yang harus dipelihara karena bermanfaat bagi pasien,dokter, maupun bagi rumah sakit. Dokumen rekam medis sangat penting dalam mengemban mutu pelayanan medik yang diberikan oleh rumah sakit dan staf mediknya serta sebagai alat bukti yang akurat di pengadilan. menurut Pasal 46 UU Praktik Kedokteran, yang dimaksud dengan rekam medis adalah: (1) Setiap dokter atau dokter gigi dalam menjalankan praktik kedokteran wajib membuat rekam medis. (2) Rekam medis sebagaimana dimaksud pada ayat (1) harus segera dilengkapi setelah pasien selesai menerima pelayanan kesehatan. (3) Setiap catatan rekam medis harus dibubuhi nama, waktu, dan tanda tangan petugas yang memberikan pelayanan atau tindakan.

Tujuan Rekam Medis Menurut Ginoby (1991) yang seringkali disingkat Alfred yaitu:

a) Aspek administrasi / Administration. Suatu berkas rekam medis mempunyai nilai administrasi karena isinya meyangkut tindakan berdasarkan wewenang dan tanggung jawab sebagai tenag medis dan paramedis dalam mencapai tujuan pelayanan kesehatan.

b) Aspek Hukum / Legal. Suatu berkas rekam medis mempunyai nilai hukum karena isinya menyangkut masalah adanya jaminan kepastian hukum atas dasar keadilan, dalam rangka usaha menegakkan hukum serta penyediaan bahan bukti untuk menegakkan keadilan.

c) Aspek keuangan / Financihal. Suatu berkas rekam medis mempunyai nilai uang karena isinya menyangkut data dan informasi yang dapat digunakan dalam menghitung biaya pengobatan/tindakan dan perawatan.

d) Aspek penelitian / Research. Suatu berkas rekam medis mempunyai nilai penelitian, karena isinya menyangkut data/informasi yang dapat dipergunakan dalam penelitian dan pengembangan ilmu pengetahuan di bidang kesehatan.

e) Aspek pendidikan / Education. Suatu berkas rekam medis mempunyai nilai pendidikan, karena isinya menyangkut data/informasi tentang perkembangan/

10 Mussakir. (2013) Putusan Hakim Yang Diskriminatif Dalam Perkara Pidana Suatu Tinjauan Sosiologi Hukum Dan Dan Psikologi Hukum. Yogjakarta: Mahakarya Rangkang Offset. h. 1.

11 Dali, M. A., \& Kasim, W. (2019). Aspek Hukum Informed Consent dan Perjanjian Terapeutik. Akademika, 8(2), 95-106, h. 7.

$$
\text { 140|S A S I Vol. } 27 \text { No.2, April - Juni } 2021
$$


kronologis dan kegiatan pelayanan medis yang diberikan kepada pasien. Informasi tersebut dapat dipergunakan sebagai bahan/referensi pengajaran di bidang profesi kesehatan.

f) Aspek dokumentasi / Documentation.Suatu berkas reka medis mempunyai nilai dokumentasi, karena isinya menyangkut sumber ingatan yang harus didokumentasikan dan dipakai sebagai bahan pertanggung jawaban.

Berdasarkan penjelasan diatas dalam hal pengaturan sistem Pembuktian Hukum Acara Pidana dalam proses penyelesaian tindak Pidana indikasi Kesalahanyang dilakukan oleh seorang dokter masih menggunakan beban pembuktian secara biasa. Hal ini dikarenakan dalam proses penyidikan terhadap suatu perkaran indikasi Kesalahanyang dilakukan oleh seorang dokter yang mengharuskan pasienlah terlebih dahulu melakukan pembuktian awal. Hal ini sebagaimana tertuang dalam Pasal 66 Kitab Undang-undang Hukum Acara Pidana (KUHAP) yang menyatakan: "Tersangka atau terdakwa tidak dibebani kewajiban pembuktian".

Menurut analisis penulis hal ini merupakan suatu hal yang dapat merugikan pasien dan Jaksa penuntut umum dimana dalam hal untuk melakukan suatu proses penyelidikan serta penyidikan mengenai kasus berindikasi Kesalahanyang dilakukan oleh dokter dikarenakan tidak dapat menjelaskan tentang hal hal medis yang tidak dipahami, oleh karena itu penulis berpendapat perlu adanya keseimbangan dalam hal penyelesaian kasus berindikasi Kesalahanyang dilakukan oleh seorang dokter dengan melakukan pengecualian dengan melakukan pembalikan beban pembuktian dalam proses penyelesaian kasus dugaan indikasi Kesalahanyang dilakukan oleh seorang dokter.

Dalam praktiknya di Indonesia proses pemberian beban pembuktian terbalik sendiri diatur didalam UU No 31 Tahun 1999 Jo UU No. 20 Tahun 2001 Tentang Pemberantasan Tindak Pidana Korupsi, terkhususnya dalam UU penerapan pembalikan beban pembuktian itu sendiri dapat dilihat Pada Pasal 37 ayat (1) yang menyatakan: Terdakwa mempunyai hak untuk membuktikan bahwa ia tidak melakukan tindak pidana korupsi.

UU No 31 Tahun 1999 Jo UU No. 20 Tahun 2001 merupakan Lex Specialis yang dalam proses beracaranya tidak semua keseluruhan yang ada didalam KUHAP sebagai Lex Generalis tidak dimasukan, salah satunya adalah proses pembuktian yang diatur didalam Undang-Undang ini yang menggunakan Pembuktian terbalik secara berimbang sebagaimana penjelasan UndangUndang ini.

Salah satu alasan lahirnya hadirnya UU ini sebagamana tertian dalam konsiderasi menimbang adalah bahwa tindak pidana korupsi yang selama ini terjadi secara meluas, tidak hanya merugikan keuangan negara, tetapi juga telah merupakan pelanggaran terhadap hak-hak sosial dan ekonomi masyarakat secara luas, sehingga tindak pidana korupsi perlu digolongkan sebagai kejahatan yang pemberantasannya harus dilakukan secara luar biasa. Berdasarkan hal tersebut dapat diketahui adanya suatu kekhususan dikarenakan permasalahan yang timbul didalam masyarakat sehingga diperlukan lahirnya suatu UU yang baru dengan suatu konsep baru untuk menjawab permasalahan yang terjadi.

Sejalan dengan hal itu jika dilihat pada permasalahan yang timbul dalam pelaksanaan penggunaan beban pembuktian dalam penyelesaian perkara kesalahan yang dilakukan dokter dapat dilihat belum memberikan suatu keadilan dalam masyarakat. Permasalahan yang terjadi dalam suatu proses pembuktian perkara kesalahan yang dilakukan oleh dokter adalah, minimnya pengetahuan bukti antara pasien dan jaksa selaku penuntut umum dengan dokter yang diukur dari konteks keilmuan di bidang kesehatan. berangkat dari hal itu penulis beranggapan perlu dibuatnya suatu konsep pembuktian terbalik dalam proses penyelesaian perkara kesalahan yang dilakukan dokter sebagai bentuk menjawab permasalahan yang ada didalam masyarakat dan merupakan hak dokter untuk memberikan pembuktian. 


\section{Perlindungan Hukum Terhadap Pasien Pada Asas Beban Pembuktian Terbalik}

Pada hakikatnya Perlindungan Hukum adalah segala upaya pemenuhan hak dan pemberian bantuan untuk memberikan rasa aman kepada saksi dan/atau korban, perlindungan hukum korban kejahatan sebagai bagian dari perlindungan masyarakat, dapat diwujudkan dalam berbagai bentuk, seperti melalui pemberian restitusi, kompensasi, pelayanan medis, dan bantuan hukum. ${ }^{12}$ Perlindungan hukum yang diberikan kepada subyek hukum ke dalam bentuk perangkat baik yang bersifat preventif maupun yang bersifat represif, baik yang lisan maupun yang tertulis. Dengan kata lain dapat dikatakan bahwa perlindungan hukum sebagai suatu gambaran tersendiri dari fungsi hukum itu sendiri, yang memiliki konsep bahwa hukum memberikan suatu keadilan, ketertiban, kepastian, kemanfaatan dan kedamaian.

Perlindungan hukum dapat diartikan sebagai perlindungan oleh hukum atau perlindungan dengan menggunakan pranata dan sarana hukum. Hukum dalam memberikan perlindungan dapat melalui cara-cara tertentu, yaitu: ${ }^{13}$

1) Membuat Peraturan (By Giving Regulation), cara ini bertujuan untuk: Memberikan hak dan kewajiban; dan Menjamin hak-hak para subyek hukum.

2) Menegakkan peraturan (By Law Enforcement), melalui: a. Hukum administrasi negara yang berfungsi untuk mencegah pelanggaran (Preventif); b. Hukum pidana yang berfungsi untuk menanggulangi pelanggaran (Repressive),dan c. Hukum perdata yang berfungsi untuk memulihkan hak (Curative; Recovery; Remedy), dengan membayar kompensasi atau ganti kerugian.

Prinsip perlindungan hukum terhadap tindakan pemerintah bertumpu dan bersumber dari konsep tentang pengakuan dan perlindungan terhadap hak-hak asasi manusia karena menurut sejarah dari barat, lahirnya konsep-konsep tentang pengakuan dan perlindungan terhadap hakhak asasi manusia diarahkan kepada pembatasan-pembatasan dan peletakan kewajiban masyarakat dan pemerintah.

Dalam merumuskan prinsip-prinsip perlindungan hukum di Indonesia, landasannya adalah Pancasila sebagai ideologi dan falsafah negara. Konsepsi perlindungan hukum bagi rakyat di Barat bersumber pada konsep-konsep Rechtstaat dan "Rule of The Law". Dengan menggunakan konsepsi Barat sebagai kerangka berfikir dengan landasan pada Pancasila, prinsip perlindungan hukum di Indonesia adalah prinsip pengakuan dan perlindungan terhadap harkat dan martabat manusia yang bersumber pada Pancasila. Prinsip perlindungan hukum terhadap tindak pemerintah bertumpu dan bersumber dari konsep tentang pengakuan danperlindungan terhadap hak-hak asasi manusia karena menurut sejarahnya di Barat, lahirnya konsep-konsep tentang pengakuan dan perlindungan terhadap hak-hak asasi menusia diarahkan kepada pembatasan-pembatasan dan peletakan kewajiban masyarakat dan pemerintah. ${ }^{14}$ Secara konseptual, perlindungan hukum yang diberikan bagi rakyat Indonesia merupakan implementasi atas prinsip pengakuan dan perlindungan terhadap harkat dan martabat manusia yang bersumber pada pancasila dan prinsip negara hukum yang berdasarkan pancasila. Perlindungan hukum hakekatnya setiap orang berhak mendapatkan perlindungan dari hukum.

Hampir seluruh hubungan hukum harus mendapat perlindungan dari hukum. Oleh karena itu terdapat banyak macam perlindungan hukum. Perbedaan dasar antara tindak pidana biasa dengan Tindak Pidana Medis terletak pada Fokus dari tindakan tersebut. Fokus tindak pidana biasa terletak dari akibat tindak pidana, sedangkan pada tindak pidana medis fokusnya adalah

12 Soekanto, S. (2006). Pengantar Penelitian Hukum, Jakarta: UI Press, h. 133.

13 HZ, E. D. (2013). Perlindungan Hukum Terhadap Anak Dari Konten Berbahaya Dalam Media Cetak Dan Elektronik, Jurnal Ilmu Hukum, 4(1), 1-20. DOI: http://dx.doi.org/10.30652/jih.v3i1.1036, h. 5.

14 Ilyas, A., \& Mustamin, M. (2012). Asas-Asas Hukum Pidana: Memahami Tindak Pidana dan Pertanggungjawaban Pidana sebagai Syarat Pemidanaan: Disertai Teori-Teori Pengantar dan Beberapa Komentar. Yogyakarta: Rangkang Education \& PuKAP-Indonesia, h. 18.

$$
142 \text { |S ASI Vol. } 27 \text { No.2, April - Juni } 2021
$$


sebab dari tindak pidana. ${ }^{15}$

a) Perbuatan yang dilakukan oleh subyek hukum.

Perbuatan pidana dapat dilakukan oleh manusia (natuurlijke person) maupun badan hukum (rechts person). Pelaku tindak pidana tertentu dapat diminta pertanggung jawabannya menurut hukum pidana. Ada perbedaan bentuk sanksi pidana yang dapat dijatuhkan antara Manusia alamiah dan Badan Hukum. Hal ini juga berlaku dalam praktik pelayanan kesehatan oleh tenaga kesehatan maupun fasilitas sarana pelayanan kesehatan.

b) Ada kesalahan

Kesalahan tindak pidana medis pada umumnya terjadi karena kelalaian yang dilakukan oleh dokter. Dalam hal ini sering terjadi dokter melakukan sesuatu yang seharusnya tidak dilakukan atau tidak berbuat sesuatu, dalam hukum pidana penentuan atas kesalahan seseorang didasarkan pada hal-hal berikut:

1) Keadaan batin orang yang melakukannya dalam hal ini disyaratkan bahwa disadari atau tidak perbuatan pelaku didasarkan pada Undang-Undang.

2) Adanya hubungan batin antara pelaku dengan perbuatan yang dilakukan.

Ukuran sebuah kesalahan dalam pelaksanaan profesi dokter berupa Kelalaian (culpa). Kelalaian yang terjadi dalam pelayanan kesehatan adalah kelalaian besar (culpa lata). Bukan kelalaian kecil (culpa levis). Penentuan kelalaian ini harus secara normative dan tidak secara fisik atau psikis karena sulit untuk mengetahui keadaan batin seseorang yang sesungguhnya. Penentuan tingkat kesalahan adanya kelalaian dokter atau tidak harus dibedakan menjadi:

1) Masa kerja dokter dengan kemampuan rata-rata

2) Dokter umum dan dokter ahli

3) Fasilitas sarana kesehatan yang tersedia pada saat dilakukan tindakan medis.

4) Faktor-faktor penunjang lainnya yang berpengaruh pada tindakan medis yang dilakukan oleh dokter.

c) Pebuatan yang dilakukan bersifat melawan hukum.

Sifat melawan hukum dari perbuatan menurut hukum pidana tidak selalu dirumuskan dalam ketentuan undang-undang. Tanda sifat melawan hukum dapat dilihat dari perbuatan atau keadaan tertentu atau akibat tertentu yang dilarang atau diharuskan oleh undang-undang. Ada 2(dua) macam ajaran melawan hukum, yaitu: ${ }^{16}$

1) Sifat melawan hukum formil, artinya perbuatan yang dilakukan telah memenuhi semua unsur yang telah ditentukan dalam undang-undang dan diancam sanksi pidana, dengan sifat melawan hukum tersebut dapat hapus berdasarkan ketentuan undang-undang.

2) Sifat melawan hukum materil, artinya perbuatan yang disyarakatkan memenuhi rumusan undang-undang dan perbuatan dirasakan tidak patut atau tercela oleh masyarakat.

d) Pelaku mampu bertanggungjawab.

Seseorang dinyatakan mampu bertanggungjawab atas perbuatannya apabila jiwanya sehat, yaitu: 1). Dapat menginsyafi makna senyatanya dari perbuatannya; 2). Perbuatan yang dilakukan dapat dipandang patut dalam pergaulan masyarakat; dan 3). Mampu untuk menentukan niat/kehendaknya dalam melakukan perbuatan

15 Irwanda, E. A., \& Din, M. (2020). Kekuatan Alat Bukti Perkara Zina dalam Perspektif Kitab UndangUndang Hukum Acara Pidana dan Qanun Hukum Acara Jinayat. Jurnal Ilmiah Mahasiswa Bidang Hukum Pidana, 4(3), 556-566, h. 4.

16 Ilyas, A (2012), Op Cit, h. 77.

$$
\text { 143|S A S I Vol. } 27 \text { No.2, April - Juni } 2021
$$


tersebut.

e) Tidak ada dasar penghapusan pidana.

Dasar penghapus pidana yang dapat dipergunakan dalam tindak pidana medis menurut KUHPidana adalah:

1) Menderita sakit jiwa (Pasal 44)

2) Overmacht/daya paksa (Pasal 48)

3) Pembelaan diri karena terpaksa (Pasal 49)

4) Melaksanakan ketentuan undang-undang (Pasal 50)

5) Melaksanakan perintah Jabatan (Pasal 51)

Beberapa perbuatan menurut KUHP yang dapat dikategorikan sebagai tindak pidana dibidang medis adalah sebagai berikut:

1. Menipu pasien (Pasal 378) :

Barang siapa dengan maksud untuk menguntungkan diri sendiri atau orang lain secara melawan hukum, dengan memakai nama palsu atau martabat palsu, dengan tipu muslihat, ataupun rangkaian kebohongan, menggerakkan orang lain untuk menyerahkan barang sesuatu kepadanya, atau supaya memberi hutang rnaupun menghapuskan piutang diancam karena penipuan dengan pidana penjara paling lama empat tahun.

2. Sengaja tidak menolong pasien (Pasal 304) :

Barang siapa dengan sengaja menempatkan atau membiarkan seorang dalam keadaan sengsara, padahal menurut hukum yang berlaku baginya atau karena persetujuan dia wajib memberi kehidupan, perawatan atau pemeliharaan kepada orang itu, diancam dengan pidana penjara paling lama dua tahun delapan bulan atau pidana denda paling banyak empat ribu lima ratus rupiah.

3. Menggugurkan kandungan tanpa indikasi medis (Pasal 299, 348, 349)

Pasal 229 : Barang siapa dengan sengaja memakai tanda kebesaran yang berhubungan dengan pangkat atau gelar yang tidak dimilikinya, diancam dengan pidana penjara paling lama empat bulan dua minggu atav pidana denda paling banyak empat ribu lima ratus rupiah.

Pasal 348 : (1) Barang siapa dengan sengaja menggugurkan atau mematikan kandungan seorang wanita dengan persetujuannya, diancam dengan pidana penjara paling lama lima tahun enam bulan. (2) Jika perbuatan itu mengakibatkan matinya wanita tersebut, diancam dengan pidana penjara paling lama tujuh tahun.

Pasal 349 : Jika seorang dokter, bidan atau juru obat membantu melakukan kejahatan berdasarkan pasal 346, ataupun melakukan atau membantu melakukan salah satu kejahatan yang diterangkan dalam pasal 347 dan 348, maka pidana yang ditentukan dalam pasal itu dapat ditambah dengan sepertiga dan dapat dicabut hak untuk menjalankan pencarian dalam mana kejahatan dilakukan.

4. Membocorkan rahasia medis pasien (Pasal 322)

(1) Barang siapa dengan sengaja membuka rahasia yang wajib disimpannya karena jabatan atau pencariannya, baik yang sekarang maupun yang dahulu, diancam dengan pidana penjara paling lama sembilan bulan atau pidana denda paling banyak sembilan ribu rupiah. (2) Jika kejahatan dilakukan terhadap seorang tertentu, maka perbuatan itu hanya dapat dituntut atas pengaduan orang itu.

5. Lalai yang menyebabkan kematian atau luka (Pasal 359 - 361)

Pasal 359 : Barang siapa karena kesalahannya (kealpaannya) menyebabkan orang lain mati, diancam dengan pidana penjara paling lama lima tahun atau pidana kurungan paling lama satu tahun.

Pasal 360 : (1) Barang siapa karena kesalahannya (kealpaannya) menyebabkan orang lain mendapat luka-luka berat, diancam dengan pidana penjara paling lama lima 
tahun atau pidana kurungan paling lama satu tahun. (2) Barang siapa karena kesalahannya (kealpaannya) menyebahkan orang lain lukaluka sedemikian rupa sehingga timhul penyakit atau halangan menjalankan pekerjaan jabatan atau pencarian selama waktu tertentu, diancam dengan pidana penjara paling lama sembilan bulan atau pidana kurungan paling lama enam bulan atau pidana denda paling tinggi empat ribu lima ratus rupiah.

Pasal 361 : Jika kejahatan yang diterangkan dalam bab ini dilakukan dalam menjalankan suatu jabatan atau pencarian, maka pidana ditamhah dengan sepertiga dan yang bersalah dapat dicahut haknya untuk menjalankan pencarian dalam mana dilakukan kejahatan dan hakim dapat memerintahkan supaya putusannya diumumkan.

6. Memberikan atau menjual obat palsu (Pasal 386)

(1) Barang siapa menjual, menawarkan atau menyerahkan barang makanan, minuman atau obat-obatan yang diketahuinya bahwa itu dipalsu, dan menyembunyikan hal itu, diancan dengan pidana penjara paling lama empat tahun. (2) Bahan makanan, minuman atau obat-obatan itu dipalsu jika nilainya atau faedahnya menjadi kurang karena sudab dicampur dengan sesuatu bahan lain.

7. Membuat surat keterangan palsu (Pasal 263 dan pasal 267)

Pasal 263 : (1) Barang siapa membuat surat palsu atau memalsukan surat yang dapat menimbulkan sesuatu hak, perikatan atau pembebasan hutang, atau yang diperuntukkan sebagai bukti daripada sesuatu hal dengan maksud untuk memakai atau menyuruh orang lain memakai surat tersebut seolah-olah isinya benar dan tidak dipalsu, diancam jika pemakaian tersebut dapat menimbulkan kerugian, karena pemalsuan surat, dengan pidana penjara paling lama enam tahun. (2) Diancam dengan pidana yang sama, barang siapa dengan sengaja memakai surat palsu atau yang dipalsukan seolah-olah sejati, jika pemakaian surat itu dapat menimbulkan kerugian.

Pasal 267 : (1) Seorang dokter yang dengan sengaja memberikan surat keterangan palsu tentang ada atau tidaknya penyakit, kelemahan atau cacat, diancam dengan pidana penjara paling lama empat tahun (2) Jika keterangan diberikan dengan maksud untuk memasukkan seseorang ke dalam rumah sakit jiwa atau untuk menahannya di situ, dijatuhkan pidana penjara paling lama delapan tahun enam bulan. (3) Diancam dengan pidana yang sama, barang siapa dengan sengaja memakai surat keterangan palsu itu seolah-olah isinya sesuai dengan kebenaran.

8. Melakukan euthanasia (Pasal 344)

Barang siapa merampas nyawa orang lain atas permintaan orang itu sendiri yang jelas dinyatakan dengan kesungguhan hati, diancam dengan pidana penjara paling lama dua belas tahun.

Perlindungan hukum didalam Undang-Undang Kesehatan sendiri mengatur tentang beberapa hal yang berhubungan dengan penyelesaian indikasi kesalahan yakni pada Pasal 58 yang berbunyi: (1) Setiap orang berhak menuntut ganti rugi terhadap seseorang, tenaga kesehatan, dan/atau penyelenggara kesehatan yang menimbulkan kerugian akibat kesalahan atau kelalaian dalam pelayanan kesehatan yang diterimanya. (2) Tuntutan ganti rugi sebagaimana dimaksud pada ayat (1) tidak berlaku bagi tenaga kesehatan yang melakukan tindakan penyelamatan nyawa atau pencegahan kecacatan seseorang dalam keadaan darurat. (3) Ketentuan mengenai tata cara pengajuan tuntutan sebagaimana dimaksud pada ayat (1) diatur sesuai dengan ketentuan peraturan perundang-undangan.

Selanjutnya dalam hal Perlindungan hukum Menurut Undang-Undang Praktik Kedokteran. Berdasarkan Pasal 64 Undang-Undang Praktik Kedokteran, apabila terjadi kesalahan yang melibatkan pelayanan kesehatan oleh dokter maka pengaduan diajukan pada Majelis Kehormatan Disiplin Kedokteran Indonesia. Pengaduan berhubungan dengan 
kesalahan dalam pelaksanaan tugas dokter ditentukan dalam Pasal 66 ayat (1) Undang-Undang Praktik Kedokteran yang berbunyi: "Setiap orang yang mengetahui atau kepentingannya dirugikan atas tindakan dokter atau dokter gigi yang menjalankan praktik kedokteran, tetapi tidak mampu mengadukan secara tertulis, dapat mengadukan secara lisan kepada Majelis Kehormatan Disiplin Kedokteran Indonesia”.

Berdasarkan hasil penelitian yang dilakukan oleh penulis, penulis mendapati bahwa dalam hal pemberian perlindungan hukum terhadap pasien dalam penyelesaian proses dugaan indikasi Kesalahanyang dilakukan oleh dokter pada peradilan pidana belum menggunakan beban pembuktian terbalik. Hal ini karena dalam proses penyelesaian kasus dugaan indikasi Kesalahanyang dilakukan oleh seorang dokter sampai saat ini masih menggunakan beban Pembuktian secara biasa.

Hal ini didasarkan pada konteks pemberian beban pembuktian antara pasien dan dokter saat ini masih menggunakan Pasal 66 KUHAP yang mengharuskan Pasien yang harus membuktikan terlebih dahulu mengenai indikasi Kesalahanyang dilakukan oleh seorang dokter. Adapun penjelasan dari Pasal 66 KUHAP yakni: "Tersangka atau terdakwa tidak dibebani kewajiban pembuktian"

Berdasarkan hasil penelitian pada konteks pemberian perlindungan hukum dari penjelasan ketiga UU diatas dapat diketahui pada proses penyelesaian perkara kesalahan yang dilakukan oleh dokter sampai saat ini belum memberikan suatu bentuk perlindunga hukum dibidang pembuktian dikarenakan masih menggunakan Pasal 66 KUHAP dalam proses penyelesaian perkara Kesalahan yang dilakukan oleh dokter.

Adapun Pendapat penulis dilakukan dengan melakukan pertimbangan dengan beberapa sudut pandang yaitu:

1) Segi Filosofi.

Bahwa berbagai masalah yang didapati didalam masyarakat yang sulit untuk membuktikan perkara kesalahan yang dilakukan oleh dokter menjadikan sulitnya masyarakat dalam mencari keadilan, selain itu UU yang saat ini digunakan dalam hal proses penyelesaian Perkara kesalahan yang dilakukan oleh dokter saat ini belum memberikan suatu proses penyelesaian yang belum memberikan keadilan di dalam masyarakat sehingga perlu kiranya di revisi undang-undang praktik kedokteran dalam hal proses penyelesaian perkara kesalahan yang dilakukan oleh dokter menggunakan sistem pembalikan beban pembuktian sebagai pengejewantahan daripada bentuk perlindungan hukum bagi pasien, dan juga dokter dalam hal ini memberikan hak untuk dokter membuktikan sebuah indikasi kesalahan tersebut adalah salah.

2) Segi Yuridis.

Pada konteksnya dari segi yuridis itu sendiri konteks pemberian beban pembuktian terbalik di Indonesia saat ini sudah dipraktikkan dalam beberapa UU Khusus dikarenakan diperlukan suatu kekhususan pada proses penyelesaiannya diantaranya diatur didalam UU Tipikor.

Terkhususnya untuk menjawab permasalahan yang terjadi didalam masyarakat dan juga konteks antara hubungan hukum antara dokter dan pasien merupakan suatu hal yang berbeda dengan tindak pidana lainnya sehingga memerlukan suatu konsep penerapan beban pembuktian terbalik dalam menjawab permasalahan yang terjadi didalam masyarakat.

3) Segi Teoritis.

Merupakan kekhususan menjadi bagian dari pada hak dokter untuk memberikan pembuktian bahwa tidak melakukan tindak pidana tanpa menghilangkan point pembuktian oleh pasien yang dalam hal ini diwakili oleh jaksa penuntut umum sebagaimana penjelasan didalam UU Tipikor sebagai rujukan penggunaan sitem Pembalikan Beban Pembuktian. 
4) Segi Sosial.

Merupakan sebuah permasalahan yang ada didalam masyarakat dikarenakan mimimnya pengetahuan antara pasien dan dokter sehingga memunculkan keresahan dalam masyarakat.

\section{P E N U T U P}

Dari keseluruhan uraian yang telah disajikan maka dapat disimpulkan bahwa sistem pembuktian Hukum Acara Pidana dalam proses penyelesaian tindak pidana indikasi kesalahan yang dilakukan oleh seorang dokter masih menggunakan beban pembuktian secara biasa, hal ini dikarenakan dalam proses penyidikan terhadap suatu perkaran indikasi kesalahan yang dilakukan oleh seorang dokter yang mengharuskan pasienlah terlebih dahulu melakukan pembuktian awal. Perlindungan Hukum merupakan suatu implementasi dari Hak asasi Manusia seseorang yang diberikan oleh negara, terkhususnya di bidang kesehatan telah dilakukan berbagai macam bentuk perlindungan hukum. Jika dikaitan antara perlindungan hukum dengan penggunaan asas pembuktian terbalik adalah tepat, hal ini didasarkan pada proses pembuktian yang terkesan sekarang belum memihak atau belum memberikan sebuah keadilan dalam penentuan proses peradilan terhadap kasus dugaan indikasi Kesalahanyang dilakukan oleh dokter.

\section{DAFTAR PUSTAKA}

\section{Jurnal}

[1] Dali, M. A., \& Kasim, W. (2019). Aspek Hukum Informed Consent dan Perjanjian Terapeutik. Akademika, 8(2), 95-106.

[2] Darmadi, A. S. M. Y. (2018). Pertimbangan Hakim Dalam Menjatuhkan Putusan Pidana Bersyarat. Jurnal Advokasi, 8(2), 179-191.

[3] Erdiansyah. (2016), Pertanggungjawaban Pidana Terhadap Dokter Atas Kesalahan Dan Kelalaian Dalam Memberikan Pelayanan Medis Di Rumah Sakit, Jurnal Ilmu Hukum, 3(2).

[4] HZ, E. D. (2013). Perlindungan Hukum Terhadap Anak Dari Konten Berbahaya Dalam Media Cetak Dan Elektronik, Jurnal Ilmu Hukum, 4(1), 1-20. DOI: http://dx.doi.org/10.30652/jih.v3i1.1036.

[5] Irwanda, E. A., \& Din, M. (2020). Kekuatan Alat Bukti Perkara Zina dalam Perspektif Kitab Undang-Undang Hukum Acara Pidana dan Qanun Hukum Acara Jinayat. Jurnal Ilmiah Mahasiswa Bidang Hukum Pidana, 4(3), 556-566.

[6] Maggalatung, A. S. (2014). Hubungan Antara Fakta Norma, Moral, Dan Doktrin Hukum Dalam Pertimbangan Putusan Hakim. Jurnal Cita Hukum, 2(2).

[7] Nakamnanu, M. J. (2016), Kekuatan Pembuktian Alat Bukti Informasi Atau Dokumen Elektronik Dalam Peradilan Perkara Pidana Korupsi, Jurnal Hukum.

[8] Ratnasari, D., Lasmadi, S., \& Sudarti, E. (2021). Kedudukan Hukum Deponeering dalam Sistem Peradilan Pidana. PAMPAS: Journal of Criminal Law, 2(1), 17-29.

[9] Sengi, E. (2019). Konsep Culpa Dalam Perkara Pidana Suatu Analisis Perbandingan Putusan Nomor 18/Pid. B/2017/PN. Tobelo. Era Hukum-Jurnal Ilmiah Ilmu Hukum, 17(2).

[10] Tambunan, L. (2014), Implementasi Perlindungan Hukum Terhadap Anak Sebagai Korban Kekerasan Psikis Dalam Rumah Tangga, Jurnal Hukum, 1-24, http://ejournal.uajy.ac.id/7172/.

\section{Buku}

[11]Ali, A. (2017). Menguak Tabir Hukum: Ed. 2, Jakarta: Kencana. 2017.

[12]Ilyas, A., \& Mustamin, M. (2012). Asas-Asas Hukum Pidana: Memahami Tindak Pidana dan Pertanggungjawaban Pidana sebagai Syarat Pemidanaan: Disertai Teori-Teori 
Pengantar dan Beberapa Komentar. Yogyakarta: Rangkang Education \& PuKAPIndonesia.

[13] Indrati, Maria Farida S. (2007). Ilmu Perundang-Undangan: Proses Dan Teknik Pembentukannya, Yogyakarta: Kanisius.

[14] Marzuki, P. M. (2017). Penelitian Hukum. Edisi Revisi, Jakarta: Kencana. 2008.

[15]Mussakir. (2013) Putusan Hakim Yang Diskriminatif Dalam Perkara Pidana Suatu Tinjauan Sosiologi Hukum Dan Dan Psikologi Hukum. Yogjakarta: Mahakarya Rangkang Offset.

[16] Soekanto, S. (2006). Pengantar Penelitian Hukum, Jakarta: UI Press. 